\title{
Response of cyclic and post-partum suckled cows to injections of synthetic LH-RH*
}

\author{
R. Webb, G. E. Lamming, N. B. Haynes, H. D. Hafs $\dagger$ \\ and J. G. Manns \$ \\ Department of Physiology and Environmental Studies, University of Nottingham, Schoolof Agriculture, \\ Sutton Bonington, near Loughborough, Leicestershire, U.K.
}

\begin{abstract}
Summary. Doses of 125,250 or $500 \mu \mathrm{g} \mathrm{LH}-\mathrm{RH}$ were injected i.m. into suckled beef cows on approximately Day 11 of an oestrous cycle synchronized by prostaglandin treatment. There was a positive linear relationship between dose of LH-RH and the area under the measured LH peak. Administration of $500 \mu \mathrm{g} \mathrm{LH}-\mathrm{RH}$ as a single injection to suckled cows 13-32 days post partum resulted in LH release but failed to induce normal ovarian activity. A small transient rise in plasma progesterone for 6-9 days occurred at the expected time after injection in $50 \%$ of animals. Administration of $500 \mu \mathrm{g} \mathrm{LH}-\mathrm{RH}$ to suckled beef cows approximately 20-30 days post partum and a second injection approximately 10 days later at the time when the resulting transient rise in plasma progesterone had returned to basal values induced normal cyclic activity (as shown by progesterone concentrations and observed oestrus) at 35 days compared with 70 days for untreated controls. Pituitary responsiveness to LH-RH, as assessed by $\mathrm{LH}$ levels, was found to increase up to 20 days post partum.
\end{abstract}

\section{Introduction}

The anoestrous period invariably observed in post-partum lactating cows is extended when they are suckled (Clapp, 1937; Wiltbank \& Cook, 1958) and milked cows usually ovulate earlier than suckled cows after calving (Casida et al., 1968). A prolonged post-partum anoestrous period in some beef cows may extend the interval between successive parturitions above the optimal period of 1 year and the present investigations were designed to study the efficacy of LH-RH treatment to induce earlier ovulation in the suckled beef cow.

The treatment of dairy cows with synthetic LH-RH causes release of LH (Kaltenbach et al., 1974; Zolman, Convey \& Britt, 1974) and when LH-RH is given 14-20 days after calving cyclic activity is initiated (Schams, Höfer, Hoffman, Ender \& Karg, 1973; Britt, Kittok \& Harrison, 1974). In the present work the effects of single and multiple LH-RH injections soon after parturition were examined in suckled beef cows. In view of the prospective commercial importance of synchronization of oestrus with prostaglandin (PG) F-2 $\alpha$ (Louis, Hafs \& Morrow, 1974; Dobson, Cooper \& Furr, 1975 ; Lamming, Hafs \& Manns, 1975), some animals were treated with LH-RH and PGF-2 $\alpha$.

\section{Materials and Methods}

\section{Experimental design and collection of blood samples}

Experiment 1. Twelve suckled beef cows ( 2 Angus $\times$ Friesian and 10 Hereford $\times$ Friesian) showing regular oestrous cycles, were given $2 \mathrm{i} . \mathrm{m}$. injections of $0.5 \mathrm{mg}$ PGF-2 $\alpha$ analogue (I.C.I. $80,996)$ in $2 \mathrm{ml}$ citrate buffer, 11 days apart, to synchronize oestrous cycles. Fourteen days after the

* Reprint requests to Professor G. E. Lamming.

$\dagger$ Present address: Department of Dairy Science, Michigan State University, East Lansing, Michigan 48823, U.S.A.

¥ Present address: Department of Physiological Science, College of Veterinary Medicine, Saskatoon, Canada. 
last PGF-2 $\alpha$ injection (i.e. approximately Day 11 of the synchronized cycle), the animals were given an i.m. injection of 125,250 or $500 \mu \mathrm{g} \mathrm{LH}-\mathrm{RH}$ (Hoechst) in $2 \mathrm{ml}$ saline. Groups A, B and C (4 cows/ group) were treated at mean times of 176.3 $\pm 20 \cdot 3,170 \cdot 7 \pm 21.9$ and $174 \cdot 0 \pm 17.4$ days post partum respectively. Blood samples for progesterone determinations were collected by jugular venepuncture every 2 or 3 days from the time of the second PGF-2 $\alpha$ injection until the oestrus following the LH-RH injections. In addition, samples for LH measurements were taken from an indwelling jugular cannula every $15 \mathrm{~min}$ for $1 \mathrm{~h}$ before until $11 \mathrm{~h}$ after the LH-RH injection, this interval being shown to cover the period of response by $\mathrm{LH}$ release.

Experiment 2. Twelve Angus $\times$ Friesian cows which had calved for the first or second time between 27 February and 6 March 1974 and were nursing a single calf were housed under natural lighting conditions. At 13-22 days post partum, representing a mean time from calving of $16.5 \pm 1.5$ days (see Table 2), 6 of the cows (Group D) were given a single i.m. injection of $500 \mu \mathrm{g} \mathrm{LH}-\mathrm{RH}$ in $2 \mathrm{ml}$ saline and the rest (Group E) were given an i.m. injection of $2 \mathrm{ml}$ saline. At 11 and 22 days after LH-RH treatment, 3 cows in Group D were given an i.m. injection of $25 \mathrm{mg}$ PGF-2 $\alpha$ (Prostin: Upjohn) in $5 \mathrm{ml}$ water and the other 3 were given an i.m. injection of $0.5 \mathrm{mg}$ I.C.I. 80,996 in $2 \mathrm{ml}$ citrate buffer. A single i.m. injection of $500 \mu \mathrm{g} \mathrm{LH}-\mathrm{RH}$ in $2 \mathrm{ml}$ saline was administered to Group $\mathrm{E}$ animals 11 days after the injection of saline alone, thus giving a range of initial treatment times with LH-RH from 23 to 32 days post partum with a mean of $26.5 \pm 1.2$ days (see Table 2 ).

The ovaries were palpated per rectum twice daily by two investigators from 1 day before to 3 days after LH-RH treatment, and thereafter twice weekly throughout the experiment.

Blood samples for progesterone determinations were collected by jugular venepuncture every 2nd day from parturition for approximately 90 days. Samples for LH measurements were taken from an indwelling jugular cannula, every $15 \mathrm{~min}$ for $1 \mathrm{~h}$ before $\mathrm{LH}-\mathrm{RH}$ or saline treatment, then at 15-min intervals for $4 \mathrm{~h}, 30 \mathrm{~min}$ for $4 \mathrm{~h}$ and every $2 \mathrm{~h}$ for a further $16 \mathrm{~h}$ after treatment. Samples were taken at similar intervals before and after PGF-2 $\alpha$ treatment but $2 \mathrm{~h}$ sampling was continued for $88 \mathrm{~h}$.

Experiment 3. Fifteen beef-type cows, which calved between 23 February and 26 August 1975 and were suckling 2 calves each, were allocated to groups and observed for signs of oestrus. Cows (3) in Group F received an i.m. injection of $500 \mu \mathrm{g} \mathrm{LH}-\mathrm{RH} 10$ days post partum. If a rise in progesterone of short duration occurred (see results of Exp. 2) a second injection of LH-RH was administered immediately the progesterone levels fell. If there was no progesterone increase, a further injection of LH-RH was given 10 days after the first. A third injection was given if abnormal progesterone output followed the second injection. The cows in Groups $\mathrm{G}$ and $\mathrm{H}$ ( 3 in each) were treated similarly except that the first injection was given at 20 and 30 days post partum, respectively. Blood samples for progesterone measurements were taken by jugular venepuncture four times a week for 90 days from calving. Samples for LH measurement were taken from an indwelling jugular cannula, every 15 min for $1 \mathrm{~h}$ before until $11 \mathrm{~h}$ after each LH-RH injection.

The 6 control animals in Group I received no hormone treatment, but blood samples for plasma progesterone determinations were taken by jugular venepuncture four times a week from parturition for 120 days of lactation.

\section{Hormone assays}

All blood samples were centrifuged at $4^{\circ} \mathrm{C}$ and $1600 \mathrm{~g}$ for $15 \mathrm{~min}$ immediately after collection and the plasma stored at $-20^{\circ} \mathrm{C}$ until assayed.

Plasma LH was measured using the assay described by Convey, Beal, Seguin, Tannen \& Lin (1976). Samples were routinely assayed in duplicate using 0.1 or $0.05 \mathrm{ml}$ plasma and all results are expressed as ng LH (NIH-LH-B9)/ml plasma. Sensitivity of the assay, defined as twice the standard deviation of blank values, was $0.25 \mathrm{ng} / \mathrm{ml}$. Accuracy was assessed by assaying known quantities of NIH-LH-B9 in assay diluent alone, and also in $0.1 \mathrm{ml}$ and $0.05 \mathrm{ml}$ aliquots of plasma from a postpartum cow. There was no significant difference between the three LH standard curves. Three separate cow plasma samples were assayed at dilutions of $1: 1,1: 2,1: 4,1: 8,1: 16$ and the linear regression lines were parallel. The intra-assay coefficient of variation for randomly selected duplicate pairs, calculated by the method of Snedecor $(1952)$, was $7 \cdot 1 \%(n=20)$ for values $<10 \mathrm{ng} / \mathrm{ml} \mathrm{and} 8 \cdot 3 \%$ 
( $n=20$ ) for values $>10 \mathrm{ng} / \mathrm{ml}$. The inter-assay coefficients of variation, expressed as the mean coefficient of variability (c.v. $=100 \times$ S.D. $/$ X), for concentration of hormone in three standard plasma samples (12 assays) was $12.7 \%$.

Plasma progesterone was determined by the technique described for sheep plasma (Haresign, Foster, Haynes, Crighton \& Lamming, 1975). Water blanks were $25.9 \pm 6.0$ (S.E.M.) pg/assay tube $(n=20)$. Average recovery of progesterone (15 assays) was $74 \cdot 1 \pm 3 \cdot 7 \%$. Within assays the coefficient of variation for recoveries was $<6.0 \%$. Sensitivity of the assay, defined as twice the standard deviation of blank values, was $25.0 \mathrm{pg} /$ tube. Accuracy was assessed by adding known quantities of progesterone to $0.25 \mathrm{ml}$ aliquots of plasma $(n=10)$ from a bullock and assaying the extracts. After addition of $0.05,0 \cdot 1,0 \cdot 2,0 \cdot 4,0 \cdot 7,1 \cdot 0,2 \cdot 0$ and $4.0 \mathrm{ng}$ progesterone $/ \mathrm{ml}, 0.05 \pm 0.01,0.09 \pm 0.01,0 \cdot 21 \pm$ $0.01,0.50 \pm 0.04,0.72 \pm 0.04,1 \cdot 14 \pm 0.04,2 \cdot 36 \pm 0.16$ and $4.73 \pm 0.34$ (S.E.M.) $\mathrm{ng} / \mathrm{ml}$ were detected respectively. Assay of a sample of cow plasma using duplicate aliquots of $0.05,0 \cdot 1,0 \cdot 15,0 \cdot 2,0.25$ and $0.3 \mathrm{ml}$ gave values of progesterone ranging from 3.2 to $3.5 \mathrm{ng} / \mathrm{ml}$. The coefficients of variation for randomly selected duplicate pairs was $4.4 \%(n=20)$ for values $>4 \mathrm{ng} / \mathrm{ml}, 8 \cdot 2 \%(n=20)$ for values between 1 and $4 \mathrm{ng} / \mathrm{ml}$ and $15.5 \%(n=20)$ for values $<1 \mathrm{ng} / \mathrm{ml}$. The inter-assay coefficient of variation for concentration of hormone in three standard plasma samples was $12 \cdot 3 \%(n=40)$.

\section{Results}

\section{Experiment I}

Progesterone measurements showed that the 12 cows were treated during the luteal phase on approximately Day 11 of the oestrous cycle. Luteal phase progesterone concentrations varied from 1.2 to $9.0 \mathrm{ng} / \mathrm{ml}$ and there was no correlation between progesterone level and LH response to LH-RH injection. Mean cycle length was $22 \cdot 1 \pm 0.9$ (S.E.M.) days with a range of $17-27$ days except for 1 cow which had an oestrous cycle of 33 days although progesterone concentration had fallen to low levels after 23 days.

The LH measurements are shown in Table 1. After a logarithmic transformation of the areas under the LH peak to standardize the variances, a completely randomized analysis of variance with partitioned sum of squares indicated that there was a significant difference $(P<0.05)$ in LH response between treatments. The $\mathrm{LH}$ response of the cows to the various doses of LH-RH was linear and there were no significant curvilinear trends. It was therefore decided to use a $500 \mu \mathrm{g}$ dose in subsequent experiments.

Table 1. LH response (mean \pm S.E.M.) of cows (4/group) to LH-RH

\begin{tabular}{ccccc}
\hline Group & $\begin{array}{c}\text { LH-RH } \\
(\mu \mathrm{g})\end{array}$ & $\begin{array}{c}\text { LH peak } \\
(\mathrm{ng} / \mathrm{ml})\end{array}$ & $\begin{array}{c}\text { Duration of } \mathrm{LH} \\
\text { peak }(\mathrm{h})\end{array}$ & $\begin{array}{c}\text { Area of LH peak } \\
(\text { arbitrary units) }\end{array}$ \\
\hline A & 125 & $9 \cdot 6 \pm 1 \cdot 4$ & $5 \cdot 3 \pm 0.4$ & $2 \cdot 7 \pm 0.4$ \\
B & 250 & $15 \cdot 5 \pm 3.0$ & $6.0 \pm 0.4$ & $4 \cdot 5 \pm 0.8$ \\
C & 500 & $26.0 \pm 5 \cdot 7$ & $7 \cdot 6 \pm 0.9$ & $7 \cdot 7 \pm 1.7$ \\
\hline
\end{tabular}

\section{Experiment 2}

There were no palpable structures in the ovaries in any of the cows before LH-RH treatment.

In Group D animals, follicular development was noted by 12 ( 2 cows) and $24 \mathrm{~h}$ after LH-RH injection. By 4 days after treatment, 1 animal had a CL, 2 had recently ruptured follicles, 2 had large follicles and one had no palpable structure; by 7 days well-defined CL were present in all 6 animals. The CL regressed rapidly after injection of PGF- $2 \alpha$ or its analogue. Follicular activity was then negligible until at least 63 days after calving, when cyclic ovarian activity resumed with the development of CL, the occurrence of which was confirmed by the change in progesterone levels.

In Group E, follicular development had occurred by $24 \mathrm{~h}$ after LH-RH treatment in 4 cows, by $36 \mathrm{~h}$ in one other and by 3 days in the sixth. Normal CL were present in all animals 7 days after LH- 
RH administration. Regression of the CL was complete by 11 (3 cows), 15 ( 2 cows) and 18 days. Subsequent ovarian changes were similar to those observed in Group D animals.

$L H$. The concentrations during the $24 \mathrm{~h}$ after injection of saline did not rise above preinjection levels. Treatment with LH-RH resulted in increased plasma LH levels in all cows. The LH concentration rose within $15 \mathrm{~min}$, peak levels were reached $90-165 \mathrm{~min}$ after injection, and the levels returned to basal values $4 \cdot 5-8 \mathrm{~h}$ after treatment (Table 2).

Table 2. Response of $\mathrm{LH}$ and progesterone concentrations after a single i.m. injection of $500 \mu \mathrm{g} L \mathrm{H}-\mathrm{RH}$

\begin{tabular}{|c|c|c|c|c|c|c|}
\hline \multirow[b]{2}{*}{$\begin{array}{l}\text { Group and } \\
\text { cow no. }\end{array}$} & \multirow[b]{2}{*}{$\begin{array}{l}\text { Time of } \\
\text { treatment after } \\
\text { calving (days) }\end{array}$} & \multicolumn{3}{|c|}{ LH } & \multicolumn{2}{|c|}{ Progesterone } \\
\hline & & $\begin{array}{l}\text { Peak conc. } \\
\text { (ng/ml) }\end{array}$ & $\begin{array}{l}\text { Duration } \\
\text { of peak } \\
\text { (h) }\end{array}$ & $\begin{array}{c}\text { Area of peak } \\
\text { (arbitrary } \\
\text { units) }\end{array}$ & $\begin{array}{l}\text { Peak height } \\
(\mathrm{ng} / \mathrm{ml})\end{array}$ & $\begin{array}{l}\text { Duration of increased } \\
\text { release (days) }\end{array}$ \\
\hline \multicolumn{7}{|l|}{ Group D } \\
\hline 2 & 22 & $22 \cdot 5$ & $7 \cdot 0$ & $4 \cdot 7$ & $4 \cdot 0$ & $>12 \cdot 0 * \dagger$ \\
\hline 3 & 20 & $32 \cdot 5$ & 6.0 & $5 \cdot 7$ & $1 \cdot 2$ & 8.0 \\
\hline 5 & 16 & $4 \cdot 4$ & $4 \cdot 5$ & $1 \cdot 0$ & 0.7 & $6.0 \dagger$ \\
\hline 7 & 13 & $12 \cdot 8$ & $6 \cdot 0$ & $2 \cdot 6$ & 1.4 & $8 \cdot 0$ \\
\hline 9 & 15 & $9 \cdot 4$ & 6.0 & $1 \cdot 0$ & $2 \cdot 5$ & $6 \cdot 0$ \\
\hline 11 & 13 & $17 \cdot 6$ & $7 \cdot 5$ & 3.6 & $<0.4$ & - \\
\hline Mean \pm S.E.M. & $16 \cdot 5 \pm 1 \cdot 5$ & $16 \cdot 5 \pm 4 \cdot 1$ & $6.2 \pm 0.4$ & $3.1 \pm 0.8$ & $1.7 \pm 0.5$ & - \\
\hline \multicolumn{7}{|l|}{ Group E } \\
\hline 1 & 27 & $21 \cdot 0$ & $8 \cdot 0$ & $5 \cdot 4$ & $<0.3$ & - \\
\hline 4 & 32 & $14 \cdot 5$ & $7 \cdot 0$ & $3 \cdot 7$ & $<0.7$ & - \\
\hline 8 & 26 & $16 \cdot 2$ & 6.0 & $3 \cdot 4$ & 1.0 & $>12 \cdot 0 * t$ \\
\hline 10 & 23 & $11 \cdot 5$ & $6 \cdot 0$ & $2 \cdot 7$ & $1 \cdot 2$ & 6.0 \\
\hline 13 & 25 & 31.9 & $7 \cdot 0$ & $6 \cdot 4$ & $2 \cdot 2$ & $9 \cdot 0$ \\
\hline 14 & 26 & $21 \cdot 5$ & $8 \cdot 0$ & $6 \cdot 3$ & 2.75 & $>12 \cdot 0^{*}$ \\
\hline Mean \pm S.E.M. & $26 \cdot 5 \pm 1 \cdot 2$ & $19 \cdot 4 \pm 2 \cdot 9$ & $7 \cdot 0 \pm 0.4$ & $4 \cdot 7 \pm 0 \cdot 6$ & $1.4 \pm 0.4$ & - \\
\hline
\end{tabular}

* Fluctuating progesterone concentrations throughout the sampling period.

† Declining progesterone concentrations because of treatment with PGF-2 $\alpha$ or its analogue.

The cows were regrouped into those injected with LH-RH before (Group 1) or after (Group 2) 20 days post partum. There was no significant difference between the groups for LH peak heights or duration (Table 3), but peak area was significantly lower in Group 1, indicating a decreased pituitary response to LH-RH $(P<0.05)$.

Table 3. LH response (mean \pm S.E.M.) to a single i.m. injection of LH-RH in cows treated 13-16 days (Group 1) or 20-32 days (Group 2) after parturition

\begin{tabular}{cccccc}
\hline Group & $\begin{array}{c}\text { No. of } \\
\text { cows }\end{array}$ & $\begin{array}{c}\text { Time of } \\
\text { treatment after } \\
\text { calving (days) }\end{array}$ & $\begin{array}{c}\text { LH peak conc. } \\
\text { (ng/ml) }\end{array}$ & $\begin{array}{c}\text { Duration of LH peak } \\
\text { (h) }\end{array}$ & $\begin{array}{c}\text { Area of peak } \\
\text { (arbitrary units) }\end{array}$ \\
\hline 1 & 4 & $14 \cdot 3 \pm 0.8$ & $11 \cdot 1 \pm 2.8$ & $6.0 \pm 0.6$ & $2 \cdot 1 \pm 0.6$ \\
2 & 8 & $25.1 \pm 1.3$ & $21.5 \pm 2.7$ & $6.9 \pm 0.3$ & $4.8 \pm 0.5$ \\
\hline
\end{tabular}

Progesterone. No correlation was found between LH concentration after LH-RH treatment and subsequent luteal activity (Table 2) as assessed by an increase in progesterone concentrations. LH-RH had no effect on plasma progesterone concentrations in 3 cows. In 6 cows, LH-RH treatment was followed within 4 days by elevated progesterone levels for a maximum of 9 days (Text-fig. 1). None showed any further progesterone elevations until at least 63 days after calving. Fluctuating progesterone levels from the time of treatment with LH-RH to the end of the sampling period was found in the other 3 cows. If progesterone was present, plasma levels declined when PGF-2 $\alpha$ or its analogue was administered. 




Text-fig. 1. Peripheral plasma progesterone (a) and LH (b) concentrations in a cow (Group E) given a single injection of $500 \mu \mathrm{g} \mathrm{LH}-\mathrm{RH}$.

\section{Experiment 3}

$L H$. Treatment with multiple injections of LH-RH resulted in increased plasma LH levels in all cows. The LH concentration rose within $15 \mathrm{~min}$, peak levels were reached 90-165 min after injection and concentrations returned to basal values 4·75-8.25 h after treatment (see Text-figs 2 and 3).

A randomized analysis of variance of plasma $\mathbf{L H}$ peak area with partitioned sum of squares indicated no significant differences in response between treatments, or between animals within treatments. There was also no significant difference in overall response between the first and second injections or an effect of the first injection on the second injection in each individual treatment. However, when individual treatment groups were considered, the LH peak area (Table 4) in Group $F$ cows treated at 10 days post partum was significantly less than that of the same cows treated at 20 days post partum ( $t$ test, $P<0.05$ ). There was no significant difference between values at 20 and 30 days, supporting the observation in Exp. 2 of a decreased pituitary response to LH-RH in cows treated before 20 days post partum.

Progesterone. Cyclic ovarian activity was presumed to be normal when high luteal levels of progesterone, followed by low levels of progesterone coincident with oestrous behaviour, were noted.

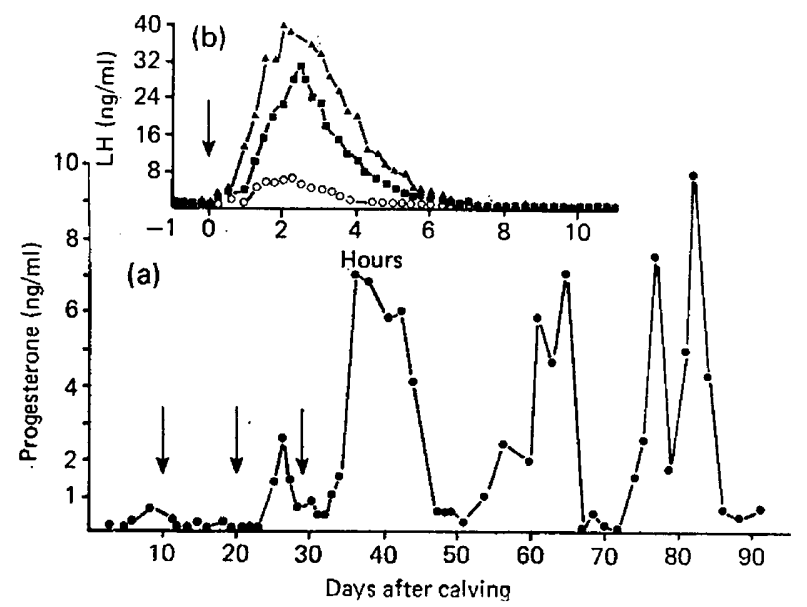

Text-fig. 2. Peripheral plasma progesterone (a) and LH (b) concentrations in a cow (Group F) given three

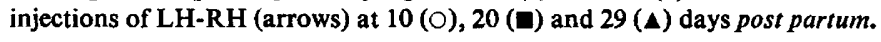




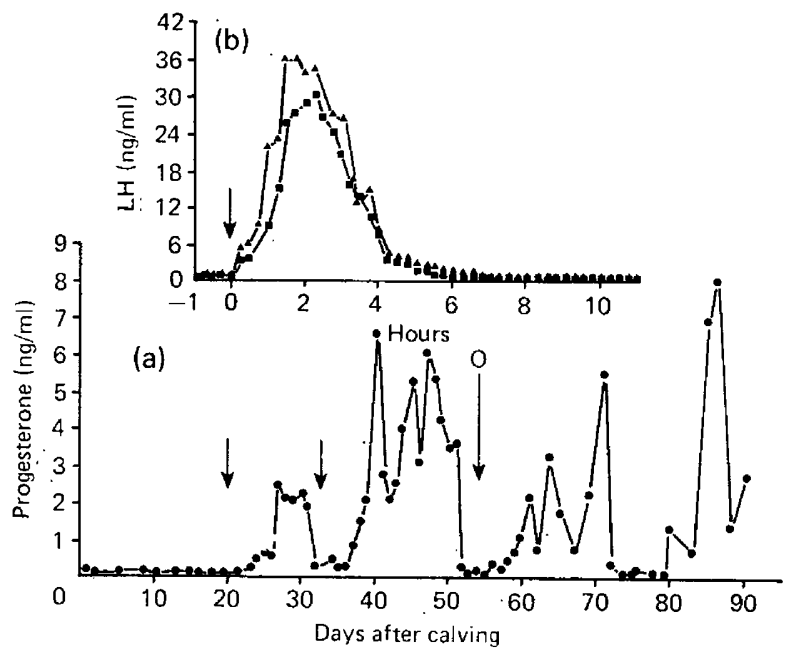

Text-fig. 3. Peripheral plasma progesterone (a) and LH (b) concentrations in a cow (Group G) given two injections of LH-RH (arrows) at 20 ( $(\mathbf{m})$ and 33 (A) days post-partum. O indicates oestrus.

Table 4. Area of LH response (arbitrary units) of suckled cows to repeated injections of LH-RH at different times after parturition

\begin{tabular}{|c|c|c|c|c|}
\hline $\begin{array}{l}\text { Group and } \\
\text { cow no. }\end{array}$ & Day 10 & Day 20 & About Day 30 & Day 40 \\
\hline \multicolumn{5}{|l|}{ Group F } \\
\hline 2 & $1 \cdot 6$ & $7 \cdot 2$ & $12 \cdot 1(29)$ & \\
\hline 3 & $3 \cdot 2$ & $7 \cdot 6$ & $3.9(28)$ & \\
\hline 53 & $5 \cdot 4$ & $9 \cdot 1$ & & \\
\hline Mean \pm S.E.M. & $3.4 \pm 1 \cdot 1^{*} \dagger$ & $8 \cdot 0 \pm 0.6^{*}$ & 8.0 & \\
\hline \multicolumn{5}{|l|}{ Group G } \\
\hline 1 & & $6 \cdot 7$ & $8 \cdot 9(31)$ & \\
\hline 86 & & $7 \cdot 4$ & $9 \cdot 5(33)$ & \\
\hline 29 & & $11 \cdot 6$ & $2.7(29)$ & \\
\hline Mean \pm S.E.M. & & $8.6 \pm 1.5 \dagger$ & $7 \cdot 0 \pm 2 \cdot 2$ & \\
\hline \multicolumn{5}{|l|}{ Group $\mathbf{H}$} \\
\hline 7 & & & $3 \cdot 1$ & $3 \cdot 1$ \\
\hline 47 & & & $10 \cdot 0$ & 5.7 \\
\hline 481 & & & $4 \cdot 7$ & \\
\hline Mean \pm S.E.M. & & & $5 \cdot 9 \pm 2 \cdot 1$ & $4 \cdot 4$ \\
\hline
\end{tabular}

* Significantly different, $P<0.05$.

$\dagger$ Significantly different, $P<0.01$.

Control animals (Group I), did not resume normal ovarian cyclic activity until $69 \cdot 7 \pm 12 \cdot 0$ (S.E.M.) days (range 36-110 days) post partum, and gave luteal phase progesterone levels of $4.4 \pm 1 \cdot 3 \mathrm{ng} / \mathrm{ml}$ plasma. In 8 of the treated cows, the progesterone analysis indicated that when an injection of LH-RH had caused a small rise in progesterone concentration, the following injection resulted in cyclic activity. Two cows in Group F required three injections of LH-RH but the other 6 animals (1 in Group F, 3 in Group G and 2 in Group H) required only 2 injections of LH-RH to initiate normal cyclic ovarian activity. The remaining cow had started cycling when treated with LH-RH at 30 days post partum. The first complete ovarian cycle in treated cows occurred at a mean of $35 \cdot 0 \pm 2 \cdot 2$ (S.E.M.) days. 


\section{Discussion}

In Exp. 1 a linear log-dose relationship described the pituitary response to LH-RH (Hoechst) in suckled cows at the mid-luteal stage of the cycle. These results are comparable with those of Schams, Höfer, Schallenberger, Hartle \& Karg (1974) who also showed a linear LH response in Brown Swiss cows using doses of up to $1500 \mu \mathrm{g} \mathrm{LH}-\mathrm{RH}$ (Hoechst). The results are, however, in contrast with those of Zolman, Convey, Britt \& Hafs (1973) whose dose-response studies on yearling Holstein heifers indicated a curvilinear relationship in which maximal $\mathrm{LH}$ release occurred in response to doses of up to $80 \mu \mathrm{g} \mathrm{LH}-\mathrm{RH}$ (Abbott) during the luteal phase of the oestrous cycle. The different results could be due to a differing potency of the releasing hormone used or variations in the types of animal. Although we observed a linear log-dose relationship a more complex relationship may exist as it was not possible in this study to show the maximal response. It was decided to use $500 \mu \mathrm{g} \mathrm{LH}-\mathrm{RH}$ in subsequent studies as it has not been shown that maximal LH release is necessary or optimal for attempts to initiate cyclic activity in the suckled cow post partum.

The maximal LH concentration in blood plasma, measured in these experiments following treatment of cows with $500 \mu \mathrm{g}$ synthetic LH-RH after 20 days post partum, was only about $60 \%$ of preovulatory LH peaks measured in two Friesian dairy cows at an equivalent stage of lactation (unpublished data). Our findings with the beef cow agree with the results of other workers (Zolman et al., 1973) who have shown that a single injection of LH-RH in cyclic dairy cows does not stimulate an elevation of plasma LH concentration comparable to that seen during the preovulatory LH surge.

LH-RH treatment induced pituitary $\mathrm{LH}$ release in all cows, but the response was variable. Analysis of the results of Exps 2 and 3 on the basis of time of LH-RH injection after parturition indicated that the response was reduced up to 20 days post partum (see Tables 3 and 4). The change in pituitary response is also in accord with the finding that pituitary LH content in the cow increased after parturition for 21-30 days (Labhsetwar, Collins, Tyler \& Casida, 1964; Saiduddin, Riesen, Graves, Tyler \& Casida, 1966; Wagner, Saatman \& Hansel, 1969). Chamley, Findlay, Cumming, Buckmaster \& Goding (1974) have demonstrated that a progressive decrease in the response of the ewe pituitary to LH-RH occurred throughout gestation and this had not returned to normal by 6 weeks after parturition.

Treatment of the suckled cow with LH-RH early after parturition (Exp. 2) resulted in follicular growth and apparently normal ovulation and CL development but subsequent luteal function, as indicated by plasma progesterone levels, was abnormal. Peripheral plasma progesterone levels were elevated as a result of treatment in most animals, but were not sustained and did not approach the normal luteal phase values of the control animals (Exp. 3). This situation is analogous to that found after treatment of anoestrous ewes with LH-RH (Haresign et al., 1975). However, as shown in Exp. 3, treatment of cows with another LH-RH injection after the transitory plasma progesterone rise appeared to initiate normal cyclic activity.

These results support the view that the release of low levels of progesterone before normal cyclic activity may be important for the development of normal reproductive activity after anoestrus (Donaldson, Bassett \& Thorburn, 1970; Yuthasastrakosol, Palmer \& Howland, 1975). It is possible that the progesterone has a feedback action on the hypothalamus and/or pituitary to initiate a pattern of gonadotrophin secretion associated with normal cyclic ovarian function. Two injections of LH-RH, the first given at 20-30 days after calving and the second approximately 10 days later, resulted in normal cyclic activity in suckled cows considerably earlier after parturition $(35 \cdot 0 \pm 2 \cdot 2$ days) than in untreated control animals (69.7 \pm 12.0 (S.E.M.) days). Despite the apparently low pituitary response to LH-RH in the first 20 days after calving, the induced LH peaks compare favourably with those obtained by Britt et al. (1974) in dairy cattle and which were followed by normal cyclic activity. This finding, together with the observations of Saiduddin et al. (1966) and Wagner et al. (1969) that suckling had no effect on pituitary LH content, suggests that the need for two injections of LH-RH to induce normal cyclic activity in suckled beef cows is not due to insufficient LH release, but perhaps to an effect of suckling.

We thank the Meat and Livestock Commission, Imperial Chemical Industries Ltd and Upjohn Ltd for financial support; Miss M. Ellison, Miss C. Reynolds, and Mr R. J. Waters, M.R.C.V.s. 
(Milk Marketing Board) for technical help; Mr W. F. Stanley and Mr J. Hargreaves for provision of animals; Mr J. M. J. Best, Hoechst Pharmaceuticals, for LH-RH; Mr M. Nelson, Upjohn Ltd, and Dr M. J. Cooper, I.C.I. Ltd, for the prostaglandin preparations; NIAMDD for NIH-LH-B9; Professor L. E. Reichert, Jr for LER-1072-2 and Dr B. J. A. Furr for progesterone antiserum. One of us (R.W.) is the recipient of a M.L.C. Postgraduate Award.

\section{References}

BritT, J.H., KitTox, R.J. \& HaRrison, D.S. (1974) Ovulation, estrus and endocrine response after GnRH in early post-partum cows. J. Anim. Sci. 39, 915-919.

Casida, L.E., Graves, W.E., Hauser, E.R., LauderDAle, J.W., RiESEN, J.W., SAIDUdDin, S. \& TYLER, W.J. (1968) Studies on the post-partum cow. Res. Bull. Coll. Agric. Life Sci., Univ. Wisconsin, No. 270, pp. 1-54.

Chamley, W.A., Findlay, J.K., Cumming, I.A., BUCKMASTER, J.M. \& Goding, J.R. (1974) Effect of pregnancy on the $\mathrm{LH}$ response to synthetic $\mathrm{GnRH}$ in the ewe. Endocrinology 94, 291-293.

Clapp, H. (1937) A factor in breeding efficiency of dairy cattle. Proc. Am. Soc. Anim. Prod. 37, 259-265.

Convey, E.M., Beal, W.E., Seguin, B.E., Tannen, K.J. \& LIN, Y.C. (1976) Gonadotrophin releasing hormone induced luteinising hormone release after prostaglandin F-2 $\alpha$ in heifers. Proc. Soc. exp. Biol. Med. 151, 84-88.

Dobson, H., COOPER, M.J. \& FurR, B.J.A. (1975) Synchronization of oestrus with I.C.I. 79,939 , an analogue of PGF-2 $\alpha$, and associated changes in plasma progesterone, oestradiol-17 $\beta$ and LH in heifers. J. Reprod. Fert. 42, 141-144.

Donaldson, L.E., BassetT, J.M. \& Thorburn, G.D. (1970) Peripheral plasma progesterone concentration of cows during puberty, oestrous cycles, pregnancy and lactation, and the effects of undernutrition or exogenous oxytocin on progesterone concentration. J. Endocr, 48, 599-614.

Haresign, W., Foster, J.P., Haynes, N.B., Crighton, D.B. \& Lamming, G.E. (1975) Progesterone levels following treatment of seasonally anoestrous ewes with synthetic LH-releasing hormone. J. Reprod. Fert. 43, 269-279.

Kaltenbach, C.C., Dunn, T.G., Kiser, T.E., CoRaH, L.R., Akbar, A.M. \& Niswender, G.D. (1974) Release of FSH and LH in beef heifers by synthetic gonadotrophin releasing hormone. J. Anim. Sci. 38, 357-362.

Labhsetwar, A.P., Collins, W.E., Tyler, J.W. \& CASIDA, L.E. (1964) Some pituitary-ovarian relationships in the periparturient cow. J. Reprod. Fert. 8, 85-90.
Laming, G.E., Hafs, H.D. \& Manns, J.G. (1975) Hormonal control of reproduction in cattle. Proc. Br. Soc. Anim. Prod. 4, 71-78.

Louis, T.M., HaFs, H.D. \& Morrow, D.A. (1974) Intrauterine administration of prostaglandin $\mathrm{F}-2 \alpha$ in cows: progesterone, estrogen, $\mathrm{LH}$, estrus and ovulation. J. Anim. Sci. 38, 347-353.

Saiduddin, S., Riesen, J.W., Graves, W.E., Tyler, W.J. \& CASIDA, L.E. (1966) Pituitary luteinizing hormone activity in the post-partum cow. J. Anim. Sci. 25, 930, Abstr.

Schams, D., Höfer, F., Hoffmann, B., Ender, M.L. \& KARG, H. (1973) Effects of synthetic LH-RH treatment on bovine ovarian function during oestrus cycle and post partum period. Acta endocr., Copenh., Suppl. 177, 296, Abstr.

Schams, D., Höfer, F., Schallenberger, E., Hartle, M. \& KARG, H. (1974) Pattern of luteinizing hormone (LH) and follicle stimulating hormone (FSH) in bovine blood plasma after injection of a synthetic gonadotropin-releasing hormone (GnRH). Theriogenology 1, 137-151.

SNEDECOR, G.W. (1952) Query 92. Biometrics 8, 85-86.

Wagner, W.C., SaAtman, R. \& Hansel, W. (1969) Reproductive physiology of the post-partum cow. II. Pituitary, adrenal and thyroid function. J. Reprod. Fert. 18, 501-508.

WiltaANk, J.N. \& Cook, A.C. (1958) The comparative reproductive performance of nursed and milked cows. J. Anim. Sci. 17, 640-648.

Yuthasastrakosol, P., Palmer, W.M. \& Howland, B.E. (1975) Luteinizing hormone, oestrogen and progesterone levels in peripheral serum of anoestrous and cyclic ewes as determined by radioimmunoassay. J. Reprod. Fert. 43, 57-65.

Zolman, J., Convey, E.M., Britt, J.H. \& Hafs, H.D. (1973) Release of bovine luteinizing hormone by purified porcine and synthetic gonadotropin releasing hormone. Proc. Soc. exp. Biol. Med. 142, 189-193.

Zolman, J., Convey, E.M. \& BRITT, J.H. (1974) Relationships between the luteinizing hormone response to gonadotropin releasing hormone and endogenous steroids. J. Anim. Sci. 39, 355-359.

Received 25 May 1976 